Boletín de la Sociedad Geológica Mexicana

VOLUMEN 65, NÚM. 3, 2013, P. 447-455

\title{
Seismic activity in the Gulf of Mexico. A preliminary analysis
}

\author{
Sara I. Franco ${ }^{1, *}$, Carles Canet $^{1}$, Arturo Iglesias ${ }^{1}$, Carlos Valdés-González ${ }^{1}$ \\ ${ }^{1}$ Instituto de Geofísica, Universidad Nacional Autónoma de México, Coyoacán 04510 México D.F., México. \\ *ivonne@sismologico.unam.mx
}

\begin{abstract}
The southwestern corner of the Gulf of Mexico (around the Isthmus of Tehuantepec) is exposed to intense deep (>100 km) seismic activity caused by the subduction of the Cocos Plate. Aside from this, the gulf has been considered a zone of low or no-seismicity. However, a sparse shallow seismic activity is observed across the Gulf of Mexico, even in the most distant areas from the plate boundaries. Some of these earthquakes have been strongly felt (e.g. 23/05/2007 and 10/09/2006), and the Jaltipan 1959 earthquake caused fatalities and severe destruction in central and southern Veracruz. In this study we analyze five relevant earthquakes that occurred since 2001. At the central Gulf of Mexico, focal mechanisms show inverse faults oriented approximately NW-SE with dip $\sim 45^{\circ}$, suggesting a link to sediment loading and/or to salt tectonics. On the other hand, we analyzed in the southwestern corner of the gulf some clear examples of strike-slip faults and activity probably related to the Veracruz Fault. One anomalous earthquake, recorded in 2007 in the western margin of the gulf, shows a strike-slip mechanism indicating a transform regime probably related with the East Mexican Fault.

The recent improvements of the Mexican Seismological broadband network have allowed the recording of small earthquakes distributed in the Gulf of Mexico. Although intermediate and large earthquakes in the region are infrequent, historic evidence indicates that magnitudes could reach $\mathrm{Mw} \sim 6.4$. This fact should be taken in consideration to reassess the seismic hazard for industrial oil infrastructure in the region.
\end{abstract}

Keywords: Strike-slip faulting, East Mexican Fault, intra-slab seismicity, salt tectonics, gravity sliding, seismic hazards.

\section{Resumen}

El Golfo de México, en su extremo meridional (alrededor del Istmo de Tehuantepec), se encuentra expuesto a una intensa actividad sísmica originada a gran profundidad (>100 km) debido al proceso de subducción de la Placa de Cocos. Dejando a un lado esta particularidad, el golfo ha sido considerado un área de baja o nula sismicidad. No obstante, se ha constatado la ocurrencia de sismos superficiales a lo largo del golfo, inclusive en las áreas más alejadas de los actuales límites de placa. Algunos de estos eventos fueron sentidos con notable intensidad (e.g. 23/05/2007 y 10/09/2006); en particular, el sismo de Jaltipan de 1959 causó decesos y destrucción en las zonas centro y sur del Estado de Veracruz. Para el presente trabajo se analizaron cinco sismos relevantes ocurridos desde 2001. En el centro del Golfo de México los mecanismos focales indican fallas inversas orientadas aproximadamente NO-SE, con buzamiento de $\sim 45^{\circ}$; el origen de los eventos podría atribuirse a la carga de sedimentos y/o a la tectónica salina. Por otro lado, en el extremo meridional del golfo se han analizado eventos superficiales claramente asociados a fallas transcurrentes derivadas, probablemente, de la Falla de Veracruz. Un sismo anómalo, registrado en 2007 en el margen occidental del golfo, muestra un mecanismo de strike-slip, lo que indicaría un régimen transformante que podría estar asociado a la Falla Oriental Mexicana.

El progreso y crecimiento que recientemente ha experimentado la red de banda ancha del Servicio Sismológico Nacional han permitido registrar frecuentes eventos menores en el Golfo de México. Aunque en el área son poco frecuentes los eventos medianos y mayores, un análisis histórico sugiere que se podrían alcanzar magnitudes de hasta Mw 6.4 . Por ello, sería recomendable que el peligro sísmico y sus efectos sobre la industria petrolera del golfo fueran objeto de nuevos estudios.

Palabras clave: Falla transcurrente, Falla Oriental Mexicana, sismicidad intra-slab, tectónica salina, deslizamiento submarino, peligros sísmicos. 


\section{Introduction}

The Gulf of Mexico (GOM) has been extensively studied from a geological approach because of the vast reserves of hydrocarbons found there, but not from a seismotectonic point of view. The GOM is currently located far from any active tectonic plate boundary (e.g. the Pacific margin); nevertheless, as reported in detail in this study, there is a conspicuous seismic activity in and around the gulf. Hereby, we present a detailed review of seismic events that occurred along the coastal areas — both onshore and offshore - of the southern and western GOM, including southern Tamaulipas, Veracruz, Tabasco, Campeche, and Yucatán, in Mexico; additionally, we are reporting events whose epicentral location fall in the central GOM (i.e. seaward beyond the continental shelf).

The seismic activity reported in the GOM consists, generally, of small earthquakes; however, three important historical events on record are noteworthy (with $\mathrm{Mw} \geq$ 5.0), in 1959, 1967 and 1978. The first two occurred in the southwestern GOM, around the northern Isthmus of Tehuantepec, and previous work (Suárez, 2000; Suárez and López, 2011) related their origin with a plate subduction process. On the other hand, the later (that of 1978), with magnitude $\mathrm{Mw}=5.0$, is the first well-recorded earthquake in the central-northern GOM, and its origin was attributed by Frohlich (1982) to the accumulation and loading of detrital sediments. In September 2006 an earthquake of magnitude $\mathrm{Mw}=5.9$ was recorded, with an epicentral location close to that of the 1978 event, being the largest seism reported hitherto in the central GOM. Gangopadhyay and Sen (2008) attributed the 2006 event to salt tectonics. From central to southern GOM, extended by an area that encompasses the Campeche Bay (Figure 1), there are large buried salt deposits of Middle Jurassic age (Salvador, 1987). The Seismological National Service (SSN, Spanish acronym) of Mexico has reported ten events in the Campeche Bay, between 1998 and 2012 (view appendix A).

In May 2007, the $\mathrm{SSN}$ recorded an earthquake $(\mathrm{Mw}=$ 5.5) off Tuxpan, in the northern Veracruz coast (Eastern Continental Shelf and Slope of the GOM), that is further north than the events described by Suárez (2000). Considering its location, it seems unlikely that this event may be related with a subduction process; moreover, its focal mechanism solution (as shown below) indicates a strike-slip event, unlike the other two events registered in the southwestern GOM (in 1959 and 1967).

The goal of this work is, besides describing the seismicity recorded in the GOM, to outline a comprehensive seismotectonic scenario of this area explaining the event distribution and focal mechanisms. It is important to note that the seismic hazard related to the GOM could be underestimated; thus, a careful analysis should be necessary to evaluate its possible impact to the extensive GOM's oil infrastructure.

\section{The Gulf of Mexico: Geological settings}

The GOM is a deep intercontinental sea located at the southeastern corner of North America (Figure 1). It covers an area in excess of 1.5 million $\mathrm{km}^{2}$ and reaches a maximum water depth of approximately $3700 \mathrm{~m}$. The gulf is a complex sedimentary basin that contains thick accumulations of detrital sediments and massive carbonates affected by complex salt tectonics (e.g. Roberts et al., 1999; Ding et al., 2010; Gradmann and Beaumont, 2012). Sediments from Mesozoic to Cenozoic ages that have accumulated in the GOM attain a maximum thickness of nearly $15000 \mathrm{~m}$ (Roberts et al., 1999).

In the area presently occupied by the GOM, the breakup of Pangaea heralded a crustal extension phase in the Late Triassic that resulted in the local development of active grabens and rift basins (Salvador, 1987). A rifting event in the Middle Jurassic opened the GOM and precipitated oceanic spreading that began in the Late Jurassic period (Pindell, 1985). Thick evaporitic series were deposited after the early opening of the GOM (Pindell, 1985), as a consequence of crustal extension that allowed intermittent seawater influx (Bird et al., 2005). Accumulated in shallow hypersaline water bodies, salt deposits are generally deformed as a consequence of an intense diapirism and sediment accumulation. The original thickness of the salt sequence was estimated by Salvador (1987) to be between 3000 and $4000 \mathrm{~m}$. However, according to the structural analysis by Hall (2002), salt thickness prior to deformation was much smaller, of ca. $300 \mathrm{~m}$ in deep-water areas. Although the precise dating of the salt deposits is uncertain, stratigraphic criteria suggest that they were formed during the Callovian age in the Middle Jurassic (Salvador, 1987); otherwise, salt deformation occurred continuously up to at least the Early Miocene (Angeles-Aquino et al., 1994).

After the opening of the GOM, a process of thermal subsidence that continued to the Early Cretaceous provided the accommodation space necessary to accumulate thick sedimentary sequences (Watkins et al., 1995). Hence, Late Jurassic to Cenozoic sediments covered the salt deposits and created a thick continental margin sedimentary wedge. The marine invasion started during the Oxfordian and ended during the Kimmeridgian (Late Jurassic), resulting in the connection of the GOM with the Atlantic Ocean (Salvador, 1987).

During the late Middle Jurassic and the Early Cretaceous, the Yucatán Block began to separate from the North American Plate due to seafloor spreading, involving at least one ocean-continent transform boundary (Bird et al., 2005). The southward displacement of the Yucatán Block to its present position can be described by a counterclockwise rotation, which is estimated to be between $42^{\circ}$ and $60^{\circ}$ in total (Bird et al., 2005 and references there in). As a consequence, the central GOM deepened and the Middle Jurassic salt deposits split in two large areas (e.g. Winker and Buffler, 1988; Salvador, 1987; Bird et al., 2005) (Figure 1), 


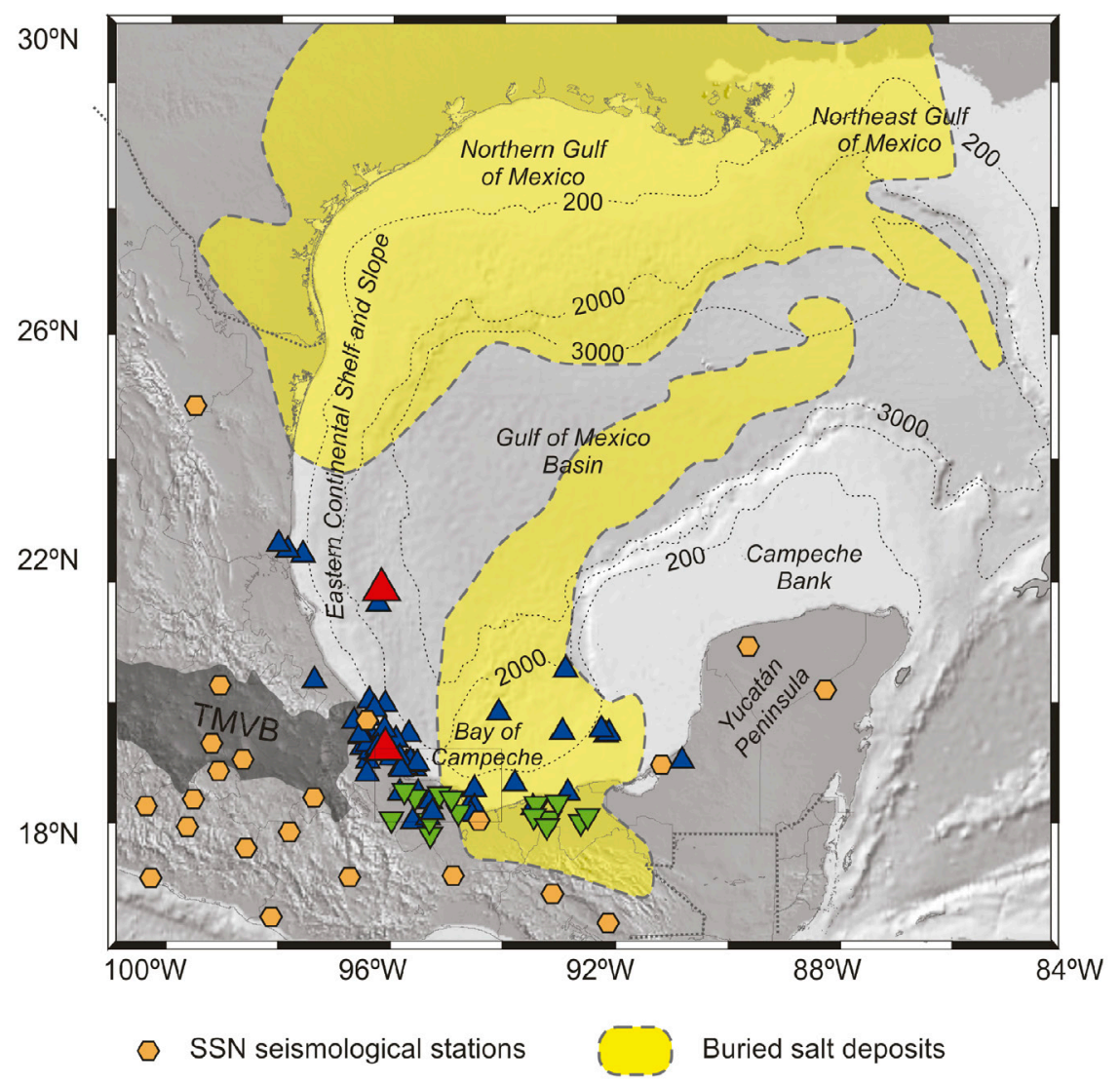

$\triangle$ Earthquakes with magnitude $M \geq 5$ (shallow; depth $\leq 70 \mathrm{~km}$ )

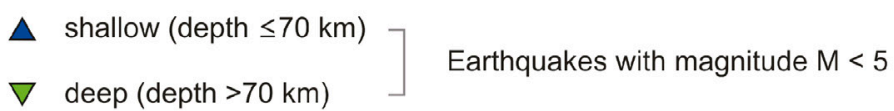

Figure 1. Distribution of earthquakes (triangles) registered by the Mexico's Servicio Sismológico Nacional (SSN) in the Gulf of Mexico, during the period between January 1, 1998, and July 31, 2012. The distribution of Jurassic salt deposits is after Bird et al. (2005). The geologic provinces of the Gulf of Mexico are according to Antoine (1972). TMVB: Trans-Mexican Volcanic Belt.

north and south of the Sigsbee abyssal plain (i.e. the deepest part of the GOM, extending in the western central gulf). The East Mexican Fault (or Shear Zone; cf. Le Roy et al., 2008), in the continental shelf off Veracruz, may have played a major role in the opening of the GOM - and the displacement of the Yucatán Block - (Pindell and Kenam, 2001). According to Rangin et al. (2008), this fault could be dextrally reactivated during Neogene times.

During the Cretaceous, the Campeche Bank was submerged and a sequence of carbonates and evaporites was deposited (Morán-Zenteno, 1984). In the Yucatán Peninsula, this sequence is covered by an undeformed Tertiary calcareous sequence.

During the Tertiary, intense salt diapirism deformed the overlying detrital sediments and, consequently, numerous allochthonous, shallow salt sheets and canopies were emplaced within the Tertiary detrital series, up to the PlioPleistocene strata (e.g. Santiago and Baro, 1990; Diegel et al., 1995; Hall, 2002). This deformation could be still active ( $c f$. Brun and Fort, 2011). Where salt domes crop out above the seafloor, submarine knolls and ridges were formed (Bryant et al., 1991; Ding et al., 2010). Salt tectonic activity occurs through both vertical movements, causing the extrusion of salt sheets, and lateral flow away from the locus of sedimentation, producing inflated salt layers (Hall, 2002). Deformation structures, related to the shallow emplacement of allochthonous salt deposits, are usually regarded as oil exploration targets (e.g. Rowan, 1995). Faults formed by salt tectonics can intersect deep hydrocarbon reservoirs, allowing the upward migration of hydrocarbons (Sassen et al., 2001); in many cases, slumps and cold seeps occur at the seafloor adjacent to fault escarpments (Bohrmann and Schenck, 2004). Thus, the shallow expressions of salt tectonics can exert a key control on the distribution of cold seeps (Ding et al., 2010). Hydrocarbon seepage, a common characteristic of the GOM seafloor, produces 
asphalt volcanism, brine pools, gas hydrates, and authigenic deposits of carbonates and barite (e.g. Canet et al., 2006).

Extending along the Eastern Continental Shelf and Slope (Figure 1) south from latitude $\sim 24^{\circ} \mathrm{N}$ are the Mexican Ridges. They consist of roughly $\mathrm{N}-\mathrm{S}$ symmetric folds affecting Tertiary strata (up to Pleistocene) that are not related to salt tectonics, but to large-scale slope mass movements (i.e. controlled by gravity tectonics) (Buffler et al., 1979). These movements, nevertheless, were possibly triggered by crustal deformation, in particular to that associated with the East Mexican Fault (Rangin et al., 2008).

\section{Methodology and data processing}

From 1998 to date the SSN has reported more than 80 events in the GOM and its western and southern margins with magnitude $M \geq 3.5$. All the events discussed in this work ( 5 events with $M \geq 4.4$; Table 1 ) were registered by the SSN broadband network. At this moment, the whole network consists of more than 55 stations distributed across the Mexican territory. For smaller seismic events $(\mathrm{M}<4.0)$, the instrumental coverage around the GOM is insufficient (Figure 1), making it difficult to determine some parameters, especially the depth.

The instrumentation at each seismological observatory comprises $(a)$ a velocity sensor (principally a STS-2 very broad band - VBB - seismic sensor), $(b)$ an accelerometer (predominantly the triaxial Epissensor or FBA-23), (c) a Baler, and $(d)$ a Quanterra Q330 digitizer. The data from each station are transmitted in real time by satellite communication.

All earthquakes were located using the crustal model of Campillo et al. (1996) and the Seisan program of Havskov and Ottemöller (1999). In appendix "A" we summarize the location and magnitude reported by the SSN for each of the events used in this work.

For events with magnitude $\leq 4.5$, the magnitude reported by the SSN is coda magnitude, and it is calculated using an empirical relationship development by SSN's staff (Espindola-Castro, pers comm., 2012): $\mathrm{Mc}=1.85$ $* \log ($ coda $)+0.0004 * \mathrm{D}+0.09$; where coda is the coda length and $\mathrm{D}$ is the epicentral distance in $\mathrm{km}$.

Since this scale begins to saturate at approximately Mc $>4.5$, for larger events the magnitude is calculated using the radiated seismic energy, Me (Singh and Pacheco, 1994). Furthermore, where possible, the seismic moment (Mo) and focal mechanism were calculated using the Automated Moment Tensor Determination (AMTD; Fukuyama and Dreger, 2000). The AMTD program was implemented in Mexico to use real time data from SSN stations (FrancoSánchez et al., 2002). A catalog of the AMTD is published in a non-official web site (http://laxdoru.geofisica.unam. $\mathrm{mx} / \sim \mathrm{cmt} /$ nouveau/pagemag.php) of the "CMT Mexican Project". The computation procedure is based on the TimeDomain Moment Tensor inversion method (TDMT_INV) developed at the Berkeley Seismological Laboratory (Dreger and Helmberger, 1993; Pasyanos et al., 1996; Dreger and Woods, 2002; Dreger, 2003). The entire threecomponent broadband displacement waveforms (Dreger and Helmberger, 1993) are inverted to obtain a moment tensor solution. The algorithm tries different depths $( \pm 30$ $\mathrm{km}$ from the initial depth), finding the solution for the depth that provides the best fit between the observed and synthetic seismograms; so, a better solution is that which has greater variance reduction (VR). The scalar seismic moment, double couple orientation components (DC) and the percentage of compensated linear vector dipole (CLVD) are obtained from the tensor decomposed; the isotropic component of moment tensor is constrained to be zero.

The range of depths reported for these events is between 5 and $44 \mathrm{~km}$; nevertheless, the deficient distribution of stations around the study zone does not allow getting a good constrain of this parameter. The AMTD inversion for different depths is sometimes useful to constraint the earthquake depth.

With the purpose of getting a complete catalogue, including the events that occurred in the central GOM, we made a search using the Global CMT project (http://www. globalcmt.org/CMTsearch.htm). The Global CMT(GCMT)

Table 1. Source parameters of the events for which it was possible calculate the moment tensor.

\begin{tabular}{cccccccccccc}
\hline \multirow{2}{*}{ Event } & Date; hh:mm (GMT) & $\begin{array}{c}\text { Long } \\
{ }^{\circ} \mathbf{E}\end{array}$ & $\begin{array}{c}\text { Lat } \\
{ }^{\circ} \mathbf{N}\end{array}$ & $\begin{array}{c}\text { Depth } \\
\mathbf{k m}\end{array}$ & Strike & Dip & Rake & $\begin{array}{c}\text { Mo } \\
(\mathbf{N} * \mathbf{m})\end{array}$ & Mw & CLVD*\% & Source \\
\hline 1 & $2001 / 10 / 09 ; 18: 48$ & -95.26 & 18.17 & 22 & 311 & 87 & -24 & $2.40 \times 10^{16}$ & 4.9 & 49 & AMTD \\
2 & $2005 / 11 / 14 ; 07: 43$ & -95.75 & 18.53 & 28 & 125 & 58 & -99 & $4.76 \times 10^{15}$ & 4.4 & 33 & AMTD \\
3 & $2006 / 09 / 10 ; 14: 56$ & -86.84 & 26.32 & 30 & 324 & 28 & 117 & $7.91 \times 10^{17}$ & 5.9 & 16 & GCMT \\
4 & $2007 / 05 / 23 ; 19: 09$ & -96.14 & 21.98 & 44 & 15 & 82 & 173 & $2.17 \times 10^{17}$ & 5.5 & 12 & AMTD \\
$4 a$ & $2007 / 05 / 23 ; 19: 09$ & -96.31 & 21.98 & 24 & 192 & 89 & -170 & $3.65 \times 10^{17}$ & 5.6 & 15 & GCMT \\
5 & $2009 / 10 / 29 ; 10: 52$ & -95.69 & 18.95 & 16 & 288 & 26 & 4 & $1.62 \times 10^{17}$ & 5.4 & 38 & AMTD \\
$5 \mathrm{a}$ & $2009 / 10 / 29 ; 10: 52$ & -95.58 & 19.14 & 17 & 310 & 25 & 59 & $4.80 \times 10^{17}$ & 5.7 & 4 & GCMT \\
\hline
\end{tabular}

* The CLVD \% was calculated following the procedure proposed by Frohlich and Apperson (1992). 
calculated the moment tensor for three events of the study area, all of them with magnitude $\mathrm{Mw} \geq 5.0$. In some cases, it was able to compare the moment tensor solution by AMTD to that obtained by the GCMT.

Table 1 shows the source parameters of 5 events, those for which it was possible to calculate the moment tensor, either using the AMTD, or the one reported by the GCMT catalogue, or both solutions. The focal mechanisms and geographical distribution of these events are shown in Figure 2.

\section{Seismicity in the Gulf of Mexico (1998-2012)}

Considering the source parameters and the event distribution, it is possible to distinguish: (a) the seismicity, shallow and deep, occurring in the southwestern GOM, around the northern Isthmus of Tehuantepec and $(b)$ in the western margin of the GOM (Eastern Continental Shelf and Slope), and (c) the shallow seismicity occurring in the central GOM.
The coastal areas of Tabasco and southern Veracruz, around the northern Isthmus of Tehuantepec, revealed an important level of seismicity; throughout the study area is where the deepest events (depth $>70 \mathrm{~km}$ ) are recorded (Figure 1). These earthquakes could be related to the intraslab seismicity in the subducted Cocos plate; therefore, down-dip tension mechanisms are expected (Engdahl and Rinehart, 1988). Pardo and Suarez (1995) stated that this type of seismicity is apparently absent further north of the Trans-Mexican Volcanic Belt (Figure 1), where, on the other hand, shallow and low magnitude events are usually recorded. The occurrence of this latter seismicity suggests that stress accumulation is taking place in this zone, despite being away of the boundary between the North American and Cocos plates. Suárez (2000), using teleseismic data, studied in detail the source parameters of two earthquakes that occurred in this zone on August $1959(\mathrm{Mw}=6.4)$ and on March 1967 (Mw =5.7). In Figure 2 the focal mechanism of these events ("a" and "b" respectively) are shown, and in Table 2 the source parameters are summarized. The SSN reported an event that occurred on October 2009 with Mw

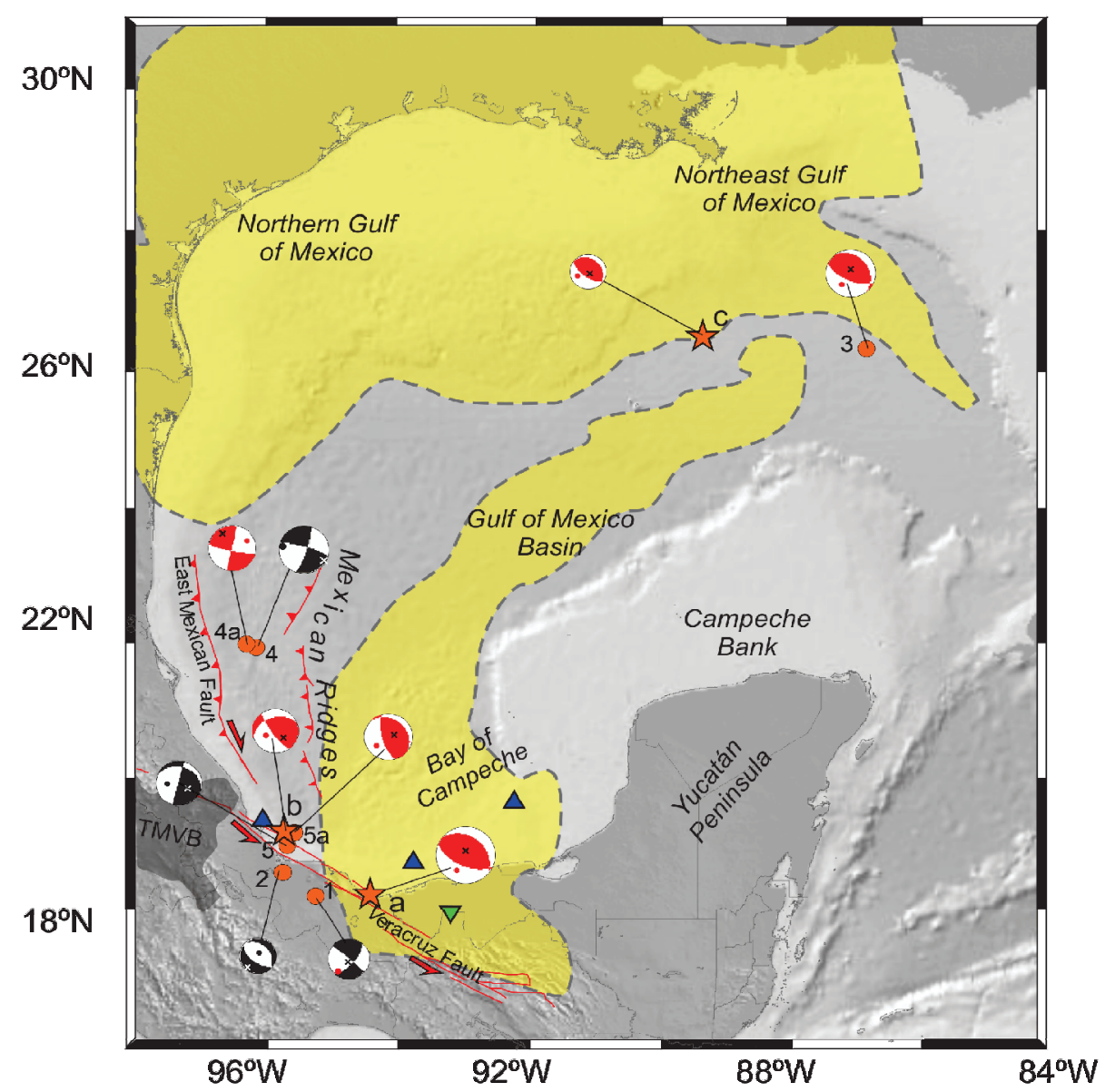

Figure 2. Distribution of earthquakes for which it has been possible to get a focal mechanism; the source parameters are listed in table 1. Circles indicate the locations of the events. Black beach balls correspond to the events reported by SNN, the red beach balls represent the events reported by Global CMT; the events 4 and 5 have been reported by both. Stars symbolize the location historic earthquakes; the source parameters are summarized in table 2. Events "a" and "b" were analyzed by Suárez (2000), and "c" is described in Flohlich (1982). Red lines represent tectonic features of the Gulf of Mexico (taken from Ragin et al., 2008). Triangles represent events with magnitude $\mathrm{M}>4.5$ but without a focal mechanism solution. For more details in symbols, see Figure 1. 
Table 2. Source parameters summarized for the most important historic earthquakes recorded in Gulf of Mexico.

\begin{tabular}{ccccccccccc}
\hline \multirow{2}{*}{ Event } & \multirow{2}{*}{ Date; hh:mm } & $\begin{array}{c}\text { LONG } \\
{ }^{\circ} \mathbf{E}\end{array}$ & $\begin{array}{c}\text { LAT } \\
{ }^{\circ} \mathbf{N}\end{array}$ & $\begin{array}{c}\text { DEPTH } \\
\mathbf{k m}\end{array}$ & Strike & Dip & Rake & $\begin{array}{c}\mathbf{M}_{\mathbf{0}} \\
(\mathbf{N} * \mathbf{m})\end{array}$ & $\mathbf{M}_{\mathbf{w}}$ & Source \\
\hline a & $1959 / 08 / 26 ; 08: 25$ & -94.43 & 18.26 & 21 & 309 & 32 & 102 & $5.00 \times 10^{19}$ & 6.4 & Suarez, 2000 \\
b & $1967 / 03 / 11 ; 14: 44$ & -95.74 & 19.23 & 26 & 250 & 39 & 20 & $3.40 \times 10^{17}$ & 5.7 & Suarez, 2000 \\
c & $1978 / 07 / 24 ; 08: 06$ & -88.79 & 26.49 & 15 & 319 & 26 & 102 & $3.48 \times 10^{16}$ & 5 & Frohlich, 1982 \\
\hline
\end{tabular}

$\sim 5.4$, close to the epicenter of the 1967 earthquake. It was possible to get source parameters for this event from both AMTD and GCMT (\#5 and \#5a, respectively, in Table 1 and Figure 2). The focal mechanisms in both solutions show a thrust fault with a slight lateral component, similar to the 1967's focal mechanism solution described by Suárez (2000). In the same area (around the northern Isthmus of Tehuantepec), in October 2001, the SSN recorded another earthquake (\#1 in Table 1 and Figure 2). It was possible to estimate the focal mechanism using AMTD (VR > 65\%) for this event. The focal mechanism corresponds to a lateral strike slip fault, which is an unexpected result. Since its magnitude is $\mathrm{Mw}=4.9$, there is no GCMT solution. Additionally, there is other strange event, labeled \#2 in Table 1 and Figure 2, with a shallow depth of $28 \mathrm{~km}$ and a normal fault mechanism.

An event was recorded by the SSN in the Eastern Continental Shelf and Slope (western margin of the GOM) on May 2007, with a magnitude $\mathrm{Mw}=5.5$ (\#4 in Table 1 and Figure 2). This event is located off Tuxpan, Veracruz ( $\Delta$ $\sim 163 \mathrm{~km}$ ), southwest of the events recorded in the central GOM (1978 and 2006). The nearest broadband station is located at $245 \mathrm{~km}$ from the epicenter and the maximum acceleration recorded was less than 1 gal. Nevertheless, at the nearest village, Tuxpan, many people reported that they felt a very strong motion (SSN's staff on duty, personal comm., 2007). The source parameters of this event, calculated using AMTD (VR=39\%), show a strike-slip faulting, similar to the GCMT focal mechanism solution. Both solutions revealed a significant CLVD component $(\sim 15 \%)$, which could be a consequence of the abnormal tectonic environment (dominated by the interaction of a detachment layer of salt or shale with the overlying sedimentary strata; Morley et al., 2011), and/or of incorrect assumptions about the velocities model (Frohlich, 1990).

The largest earthquake registered in the central GOM occurred on September 2006, with a magnitude of $\mathrm{Mw}=5.9$ (\#4 in Table 1 and Figure 2). This event is relevant because it highlights the seismogenic potential of the gulf. There is no public data about the strong ground motion, but it is well known that this event was strongly felt up to a distance of about $500 \mathrm{~km}$ (Angell and Hitchcock, 2007). The first well-recorded event in the central GOM, close to the epicentral region of 2006 event, occurred on July 1978, with magnitude $\mathrm{Mw}=5.0$ (Frohlich, 1982; event "c" in
Figure 2 and Table 2). A focal mechanism was obtained for this event, as well as a reliable location and depth. The focal mechanism represents a reverse faulting event. Frohlich (1982) explained this earthquake as the consequence of the accumulation and loading of detrital sediments. Although the occurrence of more events (1960, 1963 and 1980, among others; Frohlich, 1982) is known, it has not been possible to estimate their source parameters because only a few stations, located far away, recorded them.

\section{Discussion}

The GOM is generally regarded as a stable zone of the North American plate, outside of the influence of any plate tectonic active boundary. However, a significant seismic activity has been reported in the region. The most important activity occurs in the southwestern corner of the GOM, around the northern Isthmus of Tehuantepec, and is characterized by deep events ( $>70 \mathrm{~km}$ depth) that can be explained from intra-slab sources in the subducted Cocos plate.

Less common are shallow crustal events; this seismic activity has been recognized mainly in the coastal area of southern Veracruz (Suárez, 2000; Suárez and López, 2011). The SSN, over a period of 14 years (1998-2012), has reported four shallow events with magnitude $\mathrm{Mw}>4.0$ in the southern and western margins of the GOM and the central gulf. Previous works (e.g. Suárez, 2000; Suárez and López, 2011) have related these events to the subduction of the Cocos plate beneath the North American plate, and, likely, to the subduction of the Tehuantepec ridge enhancing stress accumulation. Suárez and López (2011) interpreted this seismicity regarding to the hypothesis of De Cserna (1981) that a plate boundary operates in the southwestern margins of the GOM. The former study included the events of May 2007 and October 2009, and a consistence of focal mechanism solutions between the October 2009 and 1967 earthquakes was found. The latter two events, along with that of 1959, suggest a deep crustal deformation in the Gulf of Mexico induced by the subduction of the Cocos plate. Nevertheless, although the focal mechanism solution reported by GCMT for the May 2007 event revealed a maximum compression axis oriented in the same direction than that of the October 2009 and 1967 events, Suárez and 
López (2011) neither accepted nor rejected that all these events (including that of 1959) have a same tectonic origin.

Andreani et al. (2008), using PEMEX seismic profiles, digital elevation models, satellite imagery and field observations, proposed the existence of a major left lateral fault, calling it Veracruz Fault (Figure 2). This neotectonic feature could be the eastern boundary of the alleged South Mexican Block. The locations of the earthquakes of 1959, 1967 and 2009 roughly coincide with the fault trace proposed by Andreani et al. (2008). Moreover, their focal mechanisms suggest a slight strike-slip component that could be related with the strike-slip motion of the Veracruz Fault. In addition to the historic earthquakes described by Suárez (2000), we found two shallow $(<30 \mathrm{~km}$ depth) earthquakes (\#1 and 5 in Table 1 and Figure 2) that lie on the probable fault trace and that have a focal mechanism solution consistent with the Veracruz Fault motion and the compressional environment described by Suárez (2000).

On the other hand, Le Roy et al.(2008), based on an extensive analysis of 2D and 3D seismic data, proposed that significant dextral transpressional deformation takes place along the western margin of the GOM (from $19^{\circ}$ to $23^{\circ}$ latitude), in particular in the Mexican Ridges. Rangin et al. (2008) associated that deformation with the existence of the East Mexican Fault (Figure 2), which is assumed to be active since the Neogene. Le Roy et al. (2008), considering the lack of seismicity recorded along this fault, suggested either a very slow motion or the cessation of activity in recent time. Nevertheless, we are reporting the occurrence of one earthquake (May 2007; $\mathrm{Mw}=5.5$ ) whose epicenter is located between the East Mexican Fault and the Mexican Ridges, an area that is under a transpressional deformation regime (Le Roy et al. 2008). The focal mechanism solution, obtained by both AMTD and CMT, shows a dextral strikeslip event consistent with the motion of the East Mexican Fault. Both solutions show a large CLVD component that could indicate particular subsurface mechanical conditions resulting from the interaction between the shale or salt detachment and the overlying strata (cf. Morley et al., 2011).

The occurrence of the 2006 and the 1978 events in the central-northern GOM could be attributed to salt tectonics. Salt diapirs undergo intense plastic deformation (the inferred distribution of salt deposits in the GOM is shown in Figures 1 and 2), so that preexisting faults in the overlaying sediments could be reactivated, producing earthquakes with variable focal mechanisms (Angell and Hitchcock, 2007). Gangopadhyay and Sen (2008), using both 2D and 3D mechanical models, demonstrated that the difference of mechanical properties between salt and detrital sediments could load stress, producing earthquakes in the GOM.

\section{Conclusions}

There is significant seismic activity in and around the GOM, although this part of the North American plate is located away from any active tectonic plate boundary. Salt tectonics, transpressional crustal deformation and gravity sliding processes (i.e. submarine, slope mass movements) occur concurrently in the GOM, resulting in a complex seismotectonic scenario.

The coastal areas of Tabasco and southern Veracruz, around the northern Isthmus of Tehuantepec, revealed a rather high level of seismicity. The occurrence of deep events $(>70 \mathrm{~km}$ depth) in this area can be explained from intra-slab sources in the subducted Cocos plate. Additionally, various shallow events were recorded (on 1959, 1967 and 2009) in this area; according to their focal mechanisms, which suggest a slight strike-slip component, they could be originated at the Veracruz Fault.

An event was recorded on May 2007 in the western margin of the GOM, off Tuxpan, with a magnitude Mw $=5.5$. This earthquake could be related to the dextral transpressional deformation that takes place in the Mexican Ridges associated to the East Mexican Fault, which is assumed to be active since the Neogene.

In the central-northern GOM, an event with magnitude of $\mathrm{Mw}=5.9$ occurred on September 2006. Considering its location and the needed stress to generate a thrust event (i.e. vertical uplift maximum stress), this event can be attributed to or related with salt tectonics. Salt deposits underlay the Campeche Bay, similarly as in the central-northern GOM (Figure 1). In the Campeche Bay, the SSN has reported the occurrence of more than 10 small events $(M<4.5)$ since 1998; therefore, this zone is not aseismic at all. Its geological and tectonics features are shared with those in the epicentral zone of the 2006 event, and we can expect that both areas have a similar seismogenic potential, i.e. to generate shallow earthquakes with magnitude $M>5.0$, such as the September 2006 earthquake.

A thorough study of the seismic environment of the GOM is recommended, especially considering that this area sustains extensive hydrocarbon extractive infrastructures that could be exposed to underestimated seismic hazard.

\section{Acknowledgements}

We want to acknowledge to all the staff that works in the SSN and has made possible this study: Jonatán Arreola Manzano, Luis Ernesto Barrón Romero, Gema V. Caballero Jiménez, Víctor Hugo Espíndola Castro, Jorge Alberto Estrada Castillo, Caridad Cárdenas Monroy, Arturo Cárdenas Ramírez, José Luis Cruz Cervantes, Daniel González Ávila, Adriana González López, Alejandro Hurtado Díaz, Casiano Jiménez Cruz, Mauricio Martínez Montero, Fernando Navarro Estrada, Jesús Antonio Pérez Santana, Iván Rodríguez Rasilla, Yi Tan Li, Leobardo Valdivia Hernández y Margarita Vidal Amaro.

We thank Zoltan De Cserna, Antoni Camprubí, Juan Carlos Montalvo and Xyoli Pérez Campos for their helpful comments and suggestions. 
The paper was improved by suggestions of anonymous revisors.

The expansion of broadband network has been made possible by funding from Secretaría de Gobernación.

\section{References}

Andreani, L., Rangin, C., Martinez-Reyes, J., Le Roy, C., Aranda-Garcia M., Le Pichon, X., Peterson-Rodriguez, R., 2008, The Neogene Veracruz Fault: evidences for left-lateral slip along the Southern Mexico Block: Bulletin de la Société Géologique de France, 179, 195-208.

Angeles-Aquino, F.J., Reyes-Nunez, J., Quezada-Muneton, J.M., MenesesRocha, J.J., 1994, Tectonic evolution, structural styles, and oil habitat in Campeche Sound, Mexico: Gulf Coast Association of Geological Societies Transactions, 44, 53-62.

Angell, M., Hitchcock, C., 2007, A geohazard perspective of recent seismic activity in the Northern Gulf of Mexico, in Offshore Technology Conference: Houston, Texas, USA, William Lettis \& Assocs. 8 p.

Antoine, J.W., 1972, Structure of the Gulf of Mexico, in Rezak, R., Henry, V.J. (eds.), Contributions on the Geological and Geophysical Oceanography of the Gulf of Mexico: Houston, Texas, U.S.A., Texas A\&M University Oceanographic Studies, Gulf Publishing Company, $303 \mathrm{p}$.

Bird, D.E., Burke, K., Hall, S.A., Casey, J.F., 2005, Gulf of Mexico tectonic history: Hotspot tracks, crustal boundaries, and early salt distribution, AAPG Bulletin, 89, 311-328.

Bohrmann, G., Schenck, S., 2004, RV SONNE cruise report SO174, OTEGA II, Balboa-Corpus Christi-Miami (1 October-12 November, 2003). GEOMAR Report 117, 130 p.

Brun, J.P., Fort, X., 2011, Salt tectonics at passive margins: Geology versus models: Marine and Petroleum Geology, 28, 1123-1145.

Bryant, R.B., Lugo, J., Córdova, C., Salvador, A., 1991, Physiography and bathymetry, in Salvador, A. (ed.), The Geology of North America the Gulf of Mexico Basin, vol. J., Geological Society of America, $160-196$.

Buffler, R.T., Shaub, F.J, Watkins, J.S., Worzel, J.L., 1979, Anatomy of the Mexican Ridges, Southwestern Gulf of Mexico: AAPG Special Volume, 29, 319-327.

Campillo, M., Singh, S.K., Shapiro, N., Pacheco, J., Herrmann, R.B., 1996, Crustal structure south of the Mexican volcanic belt, based on group velocity dispersion: Geofísica Internacional, 35, 361-370.

Canet, C., Prol-Ledesma, R.M., Escobar-Briones, E., Mortera-Gutiérrez, C., Lozano-Santa Cruz, R., Linares, C., Cienfuegos, E., MoralesPuente, P., 2006, Mineralogical and geochemical characterization of hydrocarbon seep sediments from the Gulf of Mexico: Marine and Petroleum Geology, 23, 605-619.

De Cserna, Z., 1981, Margen continental de colisión activo en la parte suroccidental del Golfo de México: Revista Mexicana de Ciencias Geológicas, 5, 255-260.

Diegel, F.A., Karlo, J.F., Schuster, D.C., Shoup, R.C., Tauvers, P.R., 1995, Cenozoic structural evolution and tectono-stratigraphic framework of the northern Gulf Coast continental margin: AAPG Memoir, 65, 109-151.

Ding, F., Spiess, V., MacDonald, I.R., Brüning, M., Fekete, N., Bohrmann, G., 2010, Shallow sediment deformation styles in north-western Campeche Knolls, Gulf of Mexico and their controls on the occurrence of hydrocarbon seepage: Marine and Petroleum Geology, 27, 959-972.

Dreger, D.S., 2003, TDMT INV: time domain seismic moment tensor inversion, in Lee, W.H.K., Kanamori, H., Jennings, P.C., Kisslinger, C. (eds.), International handbook of earthquake and engineering seismology, B: London, U.K. Academic Press, 1627.

Dreger, D.S., Helmberger, D.V., 1993, Determination of source parameters at regional distances with three- component sparse network data: Journal of Geophysical Research, 98, 8107-8125.
Dreger, D., Woods, B., 2002, Regional distance seismic moment tensors of nuclear explosions: Tectonophysics, 356, 139-156.

Engdahl, R.E., Rinehart, W.A., 1988, Seismicity map 01' North America: Geological Society of America Continental Seale Map-004.

Franco-Sánchez, S.I., Iglesias, A., Pacheco, J.F., Singh, S.K., Fukuyama, E., Pérez-Santana, J., Yi. T., 2002, Inversión automática del tensor de momentos utilizando datos de la red de banda ancha del S.S.N. (abstract), in Reunión Anual de la Unión Geofísica Mexicana, Puerto Vallarta, Jalisco, Geos 22, 379.

Frohlich, C., 1982, Seismicity of the central Gulf of Mexico: Geology, $10,103-106$

Frohlich, C., 1990, Note concerning non-double-couple source components from slip along surfaces of revolution: Journal of Geophysical Research, 95, 6861-6866.

Fukuyama E., Dreger D., 2000, Performance test of an automated moment tensor determination system for the future "Tokai" earthquake: Earth, Planets and Space, 42, 383-392.

Gangopadhyay, A., Sen, M.K., 2008, A possible mechanism for the spatial distribution of seismicity in northern Gulf of Mexico: Geophysical Journal International, 175, 1141-1153.

Gradmann, S., Beaumont, C., 2012, Coupled fluid flow and sediment deformation in margin-scale salt-tectonic systems: 2. Layered sediment models and application to the northwestern Gulf of Mexico: Tectonics, 31, TC4011.

Hall, S.H., 2002, The role of autochthonous salt inflation and deflation in the northern Gulf of Mexico: Marine and Petroleum Geology, $19,649-682$

Havskov, J., Ottemöller, L., 1999, Seisan earthquake analysis software, Seismological Research Letters, 70, 532-534.

Le Roy, C., Rangin, C., Le Pichon, X., Thi Ngoc, H.N., Andreani, L., Aranda-Garcia, M., 2008, Neogene crustal shear zone along the western Gulf of Mexico margin and its implications for gravity sliding processes. Evidences from 2D and 3D multichannel seismic data: Bulletin de la Société Géologique de France, 179, 175-185.

Morán-Zenteno, D.J., 1984, Geology of the Mexican Republic. Volume 29 of AAPG Studies in Geology: Tulsa, U.S.A., American Association of Petroleum Geologists, $160 \mathrm{p}$.

Morley, C.K., King, R., Hillis, R., Tingay, M., Backe, G., 2011, Deepwater fold and thrust belt classification, tectonics, structure and hydrocarbon prospectivity: A review: Earth-Science Reviews, 104, 41-91.

Pardo, M., Suarez, G., 1995, Shape of the subducted Rivera and Cocos plates in southern Mexico: seismic and tectonic implications: Journal of Geophysical Research, 100, 12357-12373.

Pasyanos, M.E., Dreger, D.S., Romanowicz, B., 1996, Towards realtime determination of regional moment tensors: Bulletin of the Seismological Society of America, 86, 1255-1269.

Pindell, J.L., 1985, Alleghenian reconstruction and subsequent evolution of the Gulf of Mexico, Bahamas, and Proto-Caribben: Tectonics, 4, 1-39.

Pindell, J., Kennan, L., 2001, Kinematic evolution of the Gulf of Mexico and Caribbean, in R.H. Fillon, N.C. Rosen, and P. Weimer (eds.), Petroleum Systems of Deep-Water Basins: Global and Gulf of Mexico Experience: Houston, Texas, U.S.A., GCSSEPM Foundation, 21st Annual Research Conference, 193-220 p.

Rangin, C., Le Pichon, X., Martinez-Reyes, J., Aranda-Garcia, M., 2008, Gravity tectonics and plate motions. The western margin of the Gulf of Mexico. Introduction: Bulletin de la Société Géologique de France, 179, 107-116.

Roberts, H.H., McBride, R.A., Coleman, J.M., 1999, Outer shelf and slope geology of the Gulf of Mexico: an overview, in Kumpf, H., Steidinger, K., Sherman, K. (eds.), The Gulf of Mexico Large Marine Ecosystem: Blackwell Science, 704 p.

Rowan, M.G., 1995, Structural styles and evolution of allochthonous salt, Central Louisiana Outer Shelf and Upper Slope: AAPG Memoir, $65,199-228$.

Salvador, A., 1987, Late Triassic-Jurassic paleogeography and origin of Gulf of Mexico basin: AAPG Bulletin, 71, 419-451. 
Santiago, J., Baro, A., 1990, Mexico's giant fields, 1978-1988 decade, in Halbouty, M.T. (ed.), Giant oil and gas fields of the decade 1978-1988: AAPG Memoir, 54, 73-99.

Sassen, R., Losh, S.L., Cathles III, L., Roberts, H.H., Whelan, J.K., Milkov, A.V., Sweet, S.T., DeFreitas, D.A., 2001, Massive vein-filling gas hydrate: relation to ongoing gas migration from the deep subsurface in the Gulf of Mexico: Marine and Petroleum Geology, 18, 551-560.

Singh, S.K., Pacheco, J., 1994, Magnitude determination of Mexican earthquakes: Geofísisca Internacional, 33, 189-198.

Suárez, G., 2000, Reverse faulting in the Isthmus of Tehuantepec: Backarc deformation induced by the subduction of the Tehuantepec ridge, in Delgado, H., Aguirre, G., Stock, J. (eds.), Cenozoic Tectonics and Volcanism of Mexico: Geological Society of America Special Papers, 334, 263-268 p.

Suárez, G., López, A., 2011, Crustal deformation in the southwestern Gulf of Mexico - Evidence for thrust faulting induced by the subduction of the Cocos plate, in Simposio Dr. Zoltan de Cserna: sesenta años geologizando en México: Distrito Federal, México, Instituto de Geología, UNAM, 145.
Watkins, J.S., Macrae, G., Simmons, G.R., 1995, Bipolar simpleshear rifting responsible for distribution of mega-salt basins in Gulf of Mexico?, in Travis, C.J., Harrison, H., Hudec, M.R., Vendeville, B.C., Peel, F.J., Perkins, B.F. (eds.), Salt, sediment, and hydrocarbons, Sixteenth Annual Research Conference: Houston, Texas, SEPM Foundation, Gulf Coast Section, 297-305.

Winker, C.D., Buffler, R.T., 1988, Paleogeographic evolution of early deepwater Gulf of Mexico and margins, Jurassic to Middle Cretaceous (Comanchean): AAPG Bulletin, 72, 318-346.

Manuscript received: December 13, 2012.

Corrected manuscript received: May 09, 2013.

Manuscript accepted: June 05, 2013.

\section{Appendix A.}

Location and magnitude of 81 events analyzed in this work. All this information is taken from the SSN public catalogue (http://www2.ssn.unam.mx/ website/jsp/catalogo1.jsp). The time and date is UTC time. The events with magnitude $\mathrm{M} \geq 4.5$ are highlighted in bold. The * is used to show the events for which have been possible estimate the moment tensor using AMTD. The ** indicate that the global CMT solution is also available (http://www. globalcmt.org/CMTsearch.html) for this event.

\begin{tabular}{|c|c|c|c|c|c|c|}
\hline Event & Date & Time & Mag & Lat $^{\circ} \mathbf{N}$ & Long ${ }^{\circ} \mathbf{E}$ & Depth \\
\hline 1 & $23 / 03 / 1998$ & $02: 23: 44$ & 4.4 & 18.29 & -93.4 & 77 \\
\hline 2 & 03/06/1998 & $07: 53: 40$ & 4.4 & 19.04 & -90.82 & 34 \\
\hline 3 & 21/01/1999 & $15: 20: 33$ & 4.3 & 18.26 & -94.61 & 26 \\
\hline 4 & 29/01/1999 & 01:19:53 & 4 & 17.79 & -95.3 & 159 \\
\hline 5 & 05/04/1999 & $01: 25: 43$ & 3.8 & 19.16 & -96.32 & 20 \\
\hline 6 & 28/07/1999 & $14: 52: 07$ & 3.6 & 19.99 & -96.1 & 12 \\
\hline 7 & $30 / 08 / 1999$ & $23: 03: 55$ & 3.6 & 19.76 & -96.39 & 5 \\
\hline 8 & $15 / 12 / 1999$ & $08: 14: 29$ & 3.6 & 18.5 & -95.83 & 16 \\
\hline 9 & $24 / 03 / 2000$ & $18: 58: 30$ & 4.1 & 18.91 & -95.58 & 28 \\
\hline 10 & $02 / 06 / 2000$ & $22: 44: 02$ & 4 & 18.13 & -94.48 & 46 \\
\hline 11 & $11 / 08 / 2000$ & $08: 19: 55$ & 4.1 & 19.55 & -96.41 & 7.9 \\
\hline 12 & $25 / 09 / 2000$ & $18: 22: 07$ & 3.8 & 19.22 & -96.04 & 16 \\
\hline 13 & $03 / 10 / 2000$ & $18: 25: 33$ & 4 & 18.17 & -94.79 & 78 \\
\hline 14 & $09 / 11 / 2000$ & $23: 49: 55$ & 4.2 & 18.03 & -95.31 & 72 \\
\hline 15 & $16 / 02 / 2001$ & $08: 58: 53$ & 4.1 & 18.02 & -95.6 & 37 \\
\hline 16 & $19 / 04 / 2001$ & $21: 42: 55$ & 4 & 19.19 & -95.97 & 11 \\
\hline 17 & $02 / 05 / 2001$ & $03: 20: 29$ & 3.8 & 20.05 & -96.38 & 10 \\
\hline 18 & $01 / 06 / 2001$ & $09: 51: 24$ & 3.7 & 19.27 & -96.5 & 15 \\
\hline 19 & 09/07/2001 & $13: 46: 42$ & 3.7 & 19.24 & -96.28 & 25 \\
\hline 20 & $23 / 07 / 2001$ & $06: 59: 21$ & 4 & 18.5 & -95.51 & 15 \\
\hline 21 & $09 / 10 / 2001$ & $18: 48: 21$ & 4.7 & 18.17 & -95.26 & $43^{*}$ \\
\hline 22 & $30 / 06 / 2002$ & $20: 14: 39$ & 3.9 & 19.26 & -96.17 & 16 \\
\hline 23 & $28 / 07 / 2002$ & $23: 23: 35$ & 4.4 & 21.66 & -96.22 & 16 \\
\hline 24 & $30 / 03 / 2003$ & 09:11:54 & 3.7 & 18.43 & -95.57 & 100 \\
\hline 25 & $24 / 05 / 2003$ & $16: 16: 32$ & 4.1 & 19.11 & -95.87 & 26 \\
\hline 26 & $16 / 08 / 2003$ & $07: 10: 20$ & 4 & 19.85 & -94.07 & 32 \\
\hline 27 & $14 / 10 / 2003$ & $02: 32: 47$ & 3.8 & 19.04 & -96.41 & 16 \\
\hline 28 & $20 / 10 / 2003$ & $22: 26: 58$ & 3.8 & 18.35 & -95.3 & 16 \\
\hline 29 & $25 / 12 / 2003$ & 07:06:52 & 3.9 & 18.56 & -94.51 & 52 \\
\hline 30 & $17 / 03 / 2004$ & $11: 44: 32$ & 4.3 & 18.08 & -95.34 & 64 \\
\hline 31 & $02 / 04 / 2004$ & 04:40:40 & 4.2 & 18.31 & -93.41 & 92 \\
\hline 32 & $10 / 04 / 2004$ & $01: 32: 58$ & 3.8 & 18.25 & -94.51 & 39 \\
\hline 33 & $25 / 04 / 2004$ & $18: 57: 14$ & 3.8 & 18.05 & -95.99 & 97 \\
\hline 34 & $29 / 06 / 2005$ & $16: 25: 56$ & 3.9 & 18.92 & -95.82 & 16 \\
\hline 35 & $14 / 11 / 2005$ & $07: 43: 41$ & 4.6 & 18.53 & -95.75 & $72 *$ \\
\hline 36 & $16 / 11 / 2005$ & 09:50:07 & 3.9 & 18.48 & -95.13 & 84 \\
\hline 37 & $25 / 11 / 2005$ & $05: 57: 26$ & 4.1 & 18.4 & -94.92 & 78 \\
\hline 38 & $05 / 12 / 2005$ & $06: 11: 21$ & 4.2 & 18.49 & -92.86 & 68 \\
\hline 39 & $07 / 12 / 2005$ & 09:49:16 & 3.7 & 18.15 & -94.58 & 46 \\
\hline 40 & $04 / 02 / 2006$ & $10: 27: 00$ & 3.8 & 19.27 & -96.25 & 16 \\
\hline 41 & $15 / 04 / 2006$ & $00: 31: 45$ & 3.9 & 19.45 & -96.54 & 52 \\
\hline
\end{tabular}

\begin{tabular}{|c|c|c|c|c|c|c|}
\hline Event & Date & Time & Mag & Lat $^{\circ} \mathbf{N}$ & Long $^{\circ} \mathbf{E}$ & Depth \\
\hline 42 & $08 / 12 / 2006$ & $00: 31: 22$ & 3.7 & 19.49 & -95.67 & 16 \\
\hline 43 & $09 / 02 / 2007$ & $20: 42: 25$ & 4.8 & 19.6 & -92.25 & 20 \\
\hline 44 & $11 / 02 / 2007$ & $21: 52: 42$ & 4.4 & 18.07 & -93.18 & 103 \\
\hline 45 & $12 / 02 / 2007$ & $22: 17: 05$ & 3.8 & 19.2 & -95.9 & 16 \\
\hline 46 & $23 / 05 / 2007$ & 19:09:14 & 5.4 & 21.93 & -96.16 & $22 * *$ \\
\hline 47 & $09 / 06 / 2007$ & $03: 48: 11$ & 4.4 & 18.25 & -93.47 & 11 \\
\hline 48 & $01 / 10 / 2007$ & $02: 42: 54$ & 4.5 & 18.65 & -93.79 & 63 \\
\hline 49 & $29 / 11 / 2007$ & $17: 42: 13$ & 4.5 & 17.94 & -93.22 & 87 \\
\hline 50 & $23 / 04 / 2008$ & $11: 11: 47$ & 4.1 & 18 & -92.62 & 114 \\
\hline 51 & $25 / 04 / 2008$ & $21: 36: 41$ & 4.3 & 18.1 & -92.5 & 121 \\
\hline 52 & $27 / 06 / 2008$ & $02: 33: 03$ & 4 & 19.4 & -95.91 & 22 \\
\hline 53 & $24 / 09 / 2008$ & 01:46:05 & 4.3 & 22.46 & -97.56 & 11 \\
\hline 54 & $31 / 10 / 2008$ & $01: 45: 27$ & 4.1 & 22.54 & -97.83 & 25 \\
\hline 55 & $27 / 01 / 2009$ & $07: 23: 33$ & 4.2 & 18.11 & -93.45 & 78 \\
\hline 56 & $01 / 06 / 2009$ & $11: 21: 26$ & 4 & 18.34 & -93.03 & 132 \\
\hline 57 & $17 / 08 / 2009$ & 07:19:01 & 3.8 & 19.91 & -96.29 & 5 \\
\hline 58 & $21 / 10 / 2009$ & $00: 40: 56$ & 3.6 & 19.19 & -96.36 & 16 \\
\hline 59 & $29 / 10 / 2009$ & $10: 52: 57$ & 5.5 & 18.95 & -95.69 & $20 * *$ \\
\hline 60 & $29 / 10 / 2009$ & $23: 25: 20$ & 4.2 & 18.93 & -95.74 & 21 \\
\hline 61 & $01 / 11 / 2009$ & $15: 24: 47$ & 3.8 & 19 & -95.72 & 24 \\
\hline 62 & $29 / 11 / 2009$ & 19:05:04 & 4 & 18.99 & -95.59 & 22 \\
\hline 63 & $06 / 12 / 2009$ & $09: 42: 44$ & 3.5 & 19.17 & -96.25 & 16 \\
\hline 64 & $15 / 12 / 2009$ & $11: 13: 40$ & 3.8 & 19.32 & -96.4 & 26 \\
\hline 65 & $19 / 02 / 2010$ & $02: 49: 47$ & 4.3 & 19.04 & -95.65 & 30 \\
\hline 66 & $06 / 06 / 2010$ & $10: 25: 56$ & 3.5 & 20.39 & -97.35 & 26 \\
\hline 67 & $23 / 01 / 2011$ & $05: 46: 16$ & 4.3 & 19.5 & -92.12 & 10 \\
\hline 68 & $10 / 02 / 2011$ & $12: 29: 58$ & 4 & 19.47 & -92.18 & 15 \\
\hline 69 & $13 / 05 / 2011$ & $00: 33: 42$ & 4 & 18.82 & -96.42 & 31 \\
\hline 70 & $20 / 05 / 2011$ & $21: 54: 27$ & 3.9 & 19.29 & -96.11 & 16 \\
\hline 71 & $19 / 08 / 2011$ & $15: 44: 45$ & 3.9 & 19.57 & -96.11 & 20 \\
\hline 72 & $22 / 08 / 2011$ & $19: 23: 45$ & 3.7 & 19.27 & -96.23 & 20 \\
\hline 73 & $13 / 09 / 2011$ & $13: 17: 43$ & 3.9 & 19.09 & -95.83 & 20 \\
\hline 74 & $28 / 09 / 2011$ & $10: 51: 19$ & 4.1 & 19.71 & -96.65 & 23 \\
\hline 75 & $04 / 12 / 2011$ & $13: 41: 32$ & 3.9 & 19 & -95.52 & 16 \\
\hline 76 & $14 / 02 / 2012$ & $06: 52: 35$ & 4.5 & 19.27 & -96.1 & 16 \\
\hline 77 & $04 / 04 / 2012$ & $02: 28: 28$ & 3.9 & 20.56 & -92.9 & 5 \\
\hline 78 & $04 / 04 / 2012$ & $06: 10: 58$ & 4 & 19.52 & -92.95 & 5 \\
\hline 79 & $17 / 05 / 2012$ & $10: 29: 48$ & 4.2 & 19.09 & -95.99 & 22 \\
\hline 80 & $25 / 06 / 2012$ & $01: 52: 52$ & 4.1 & 22.64 & -97.99 & 16 \\
\hline 81 & $06 / 07 / 2012$ & $05: 32: 24$ & 4.1 & 19.48 & -96.54 & 17 \\
\hline
\end{tabular}

